\title{
35. Note on the Habitat of Rock-boring Molluscs on the Coast of Central Japan."
}

\author{
By Ikusaku AmemiYa and Yasuo OHSima.
}

Fishery Institute, Faculty of Agriculture, Tokyo Imperial University.

(Comm. by A. Imamura, M.I.A., Mar. 13, 1933.)

Deep, tubular perforations made in rocks of the seashore by rockboring molluses remain for a long time after the death of the animals, since rocks withstand weathering, especially, when they lie above water. Thus, ancient earthquakes which have heaved up the land have left their geographical records upon the rock strata; holes of rock-boring molluses after their death are preserved very long, clustered in zones. In some cases the extent to which past earthquakes had lifted the land is clearly shown by zonal impressions of the ancient habitat of the molluses. Examples of these are common on the Pacific coast of Central Japan, and the marks left on the vertical rock walls on the sea coast occupy positions higher than the present sea being now exposed to the air or else situated some distance from the present shore.

The present study was undertaken to ascertain the species of the rock-boring molluses and their habitats, chiefly in relation to the kinds of rocks favoured by them, the zones of their living homes, size and form of their holes, etc. While these matters are interesting biologically, they may also be of assistance in the study of earthquakes.

On the Pacific coast of Central Japan, seven species of borers, namely, (1) Barnea fragilis Sowerby, (2) Zirfaea crispata Linné, (3) Pholadidea penita Conrad, (4) Parapholas quadrizonata Spenger, (5) Jouannetia globosa Quoy et Gaimard, (6) J. japonica Yokoyama and (7) Lithophaga curta Lischke attack deep into the rocks.

The rocks attacked by these creatures are in general soft with rather homogeneous consistency. Hard rocks and those of conglomeratic nature, even when very brittle, are not attacked. On the contrary, fairly hard rocks of homogeneous consistency are liable to be attacked.

It is quite probable that the boring has little to do with the chemical nature of the rock, as the animals bore also rocks consisting of compounds which are chemically very stable. List ${ }^{2)}$ (p. 144) noted that

1) This study was made possible with the aid of a grant made by the Imperial Academy.

2) T. List: Die Mytiliden. Fauna u. Flora d. Golfes v. Neapel. Bd. XXVII, 1902. 
No. 3.] Note on the Habitat of Rock-boring Molluses on the Coast of Central Japan. 121

Lithophaga bore always and only into calcareous rock, but in our case Lithophaga and others bore non-calcareous rocks as well as calcareous substrata, as is shown below.

The rocks attacked by our borers are all tuffaceous, no other suitable rock for boring being found in the regions studied by us. They are of four kinds; soft tuffaceous mud-stone; soft, brittle tuffaceous sand-stone; fine tuffaceous sand-stone; and coarse tuffaceous sand-stone. They are all soft rocks, and their grade of hardness is in the order just mentioned. Certain kinds of borers also bore into shells of other molluscs, such as the oyster, Ostrea circumpicta Pils., the ear-shell, Haliotis gigantea Gml. and the top-shell, Turbo cornutus Solander.

To a certain extent there seems to be a relation between the species of rock-borers and the kinds of rocks or grades of hardness, as is shown in the following table.

TABLE I. Boring molluses and kinds of substratum.

\begin{tabular}{|c|c|c|c|c|c|c|c|}
\hline \multirow[b]{2}{*}{ Species } & \multirow{2}{*}{$\begin{array}{l}\text { Tufface- } \\
\text { ous mud- } \\
\text { stone }\end{array}$} & \multicolumn{3}{|c|}{ Tuffaceous sand-stone } & \multicolumn{3}{|c|}{ Shell } \\
\hline & & $\begin{array}{l}\text { soft, } \\
\text { brittle }\end{array}$ & fine & coarse & Haliotis & Ostrea & Turbo \\
\hline Barnea & $t+t+$ & + & - & - & - & - & - \\
\hline Zirfaea & ++ & 一 & $+t+$ & - & - & - & - \\
\hline Pholadidea & + & 一 & $+t+$ & ++ & $?$ & + & 一 \\
\hline Parapholas. & - & 一 & $+t$ & $++t$ & 一 & 一 & 一 \\
\hline J. globosa. & + & 一 & + & - & - & - & - \\
\hline J. japonica & + & 一 & + & - & - & - & - \\
\hline Lithophaga & ++ & 一 & $+t+$ & sparse & + & + & + \\
\hline
\end{tabular}

Generally the boring occurs in rock walls either much inclined or vertical and less frequently in horizontal surfaces, except in the case of Barnea, which seems to prefer a horizontal surface. The boring is perpendicular to the rock surface and straight from the mouth to the end of the hole in Parapholas and Lithophaga, often not perpendicular 
and more or less curved in Pholadidea and Barnea, while they are inclined and curved in Zirfaea and Jouannetia.

As the depth of the hole from mouth to end varies according to the species and also to the size of the individual animal, in our investigation we purposely measured only depths of holes of mature animals or those in the "resting stage." The result is shown in the following table.

TABLE II. Depth of holes.

\begin{tabular}{l|r|r|r|r|r|r|r}
\hline \multicolumn{1}{c|}{ Species } & Parapholas & Pholadidea & Zirfaea & Barnea & $J$. globosa & J. japonica & Lithophaga \\
\hline Maximum & $69 \mathrm{~mm}$ & $73 \mathrm{~mm}$ & $180 \mathrm{~mm}$ & $109 \mathrm{~mm}$ & $50 \mathrm{~mm}$ & $19 \mathrm{~mm}$ & $92^{\mathrm{mm}}$ \\
\hline Minimum & 29 & 39 & $(70)$ & $(17)$ & 34 & 9 & $(11)$ \\
\hline Mean & 45 & 53 & $(122)$ & $(66)$ & 40 & 15.7 & $(39.5)$ \\
\hline Mode & 48 & 57 & $(120)$ & $(5.5-60)$ & - & 13 & $(35-40)$ \\
\hline $\begin{array}{l}\text { No. of indiv. } \\
\text { used }\end{array}$ & 50 & 50 & 50 & $(200)$ & 5 & 50 & 100 \\
\hline \begin{tabular}{l} 
Locality \\
\hline
\end{tabular} & Misaki & Misaki & Misaki & $\begin{array}{c}\text { Mera \& } \\
\text { Yoko- }\end{array}$ & Mera & Misaki & Misaki \\
\hline
\end{tabular}

For every species the largest diameter of the hole is near its end, where the animal rests, and where it measures slightly more than the shell itself, although there is very little spare room, no more than is enough to allow the animal to rotate in it. This does not apply to the Lithophaga. In Lithophaga, the hole is not circular, but flattened, thus fitting closely the form of the animal body, so that the rotation of the animal in the hole or the sheath is hindered, only its antero-posterior movement being possible. The largest diameter of the hole of each of the species studied is as follows:

$\begin{array}{ccccccc}\text { Parapholas } & \text { Pholadidea } & \text { Zirfaea } & \text { Barnea } & J . \text { globosa } & J . \text { japonica } & \text { Lithophaga } \\ 23.5^{\mathrm{mm}} & 28^{\mathrm{mm}} & 22^{\mathrm{mm}} & 18^{\mathrm{mm}} & 22^{\mathrm{mm}} & 8^{\mathrm{mm}} & 26^{\mathrm{mm}}\end{array}$

The diameter in the above table is the space, not taking into account the sheath, if it exists. By comparing this table with Table II, it will be seen that some of the holes are wide and short, while others, on the contrary, are narrow and deep.

Excepting the case in which the suitable rock is submerged under 
No. 3.] Note on the Habitat of Rock-boring Molluses on the Coast of Central Japan. 123

water and fresh rock surface is available for the rock-borers in favourable seasons, they usually live in the zone between tidal marks, the range of their vertical distribution varying more or less according to the species. In every species, the highest limit of distribution is well defined and rather easy to recognise, whereas the lowest limit, on the contrary, is very obscure. The existence of living specimens at unexpected depths below water has been recorded by us and others as well. Pholadidea penita, for example, was dredged even from a depth of 50 fathoms.' However, as sea level has an important influence on the habitation of rock-borers, the zone that is thickly inhabited by them is not so wide vertically and is quite restricted in extent. The following diagram shows graphically the vertical distribution of rock-borers as referred to sea level.

Diagram. Vertical distribution of rock-borers. Depth in $\mathrm{cm}$.

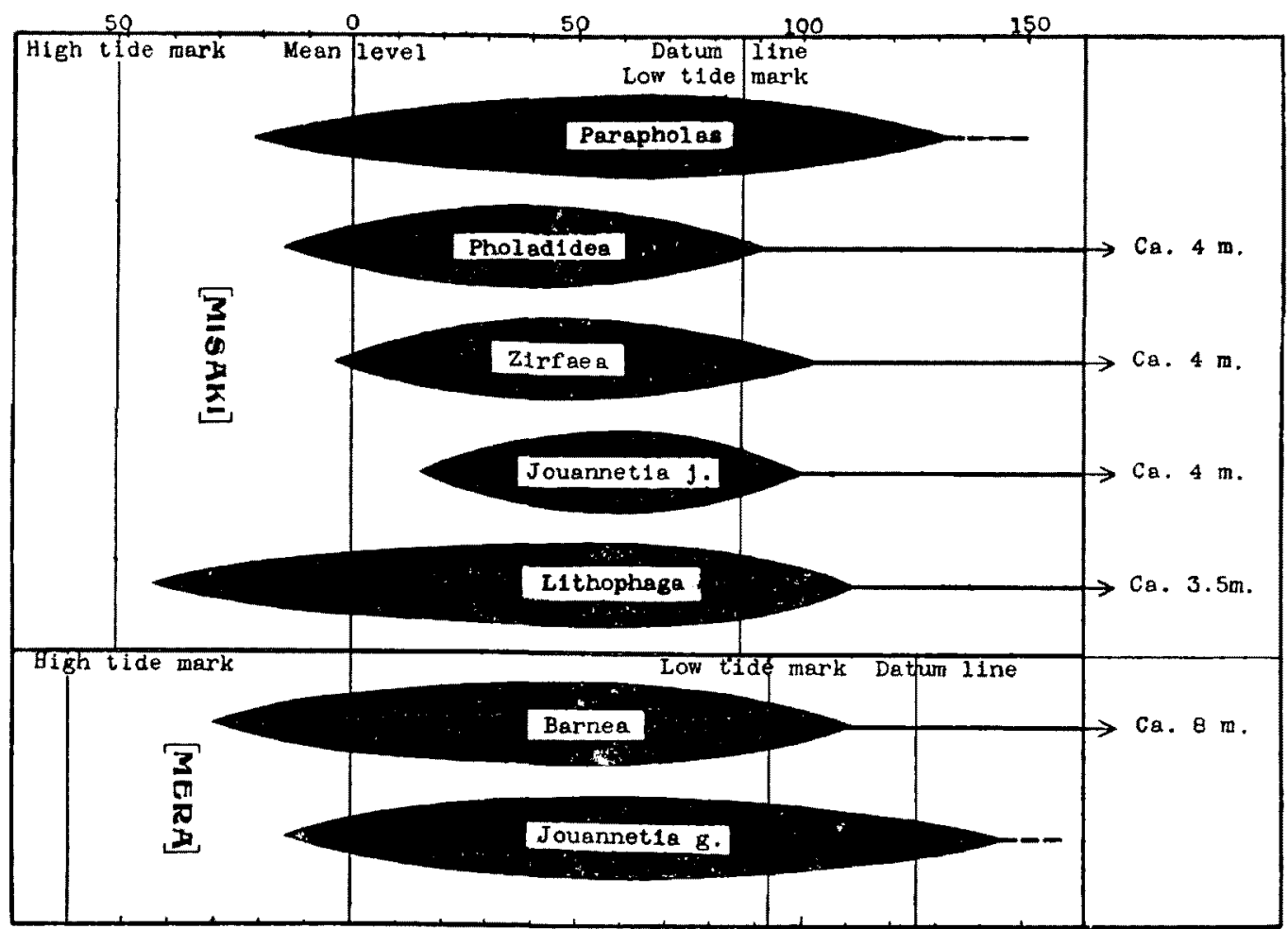

Thickness represents the grade of frequency of occurrence of the species.

1) San Francisco Bay Marine Piling Survey. 3rd. Ann. Progress Rpt. 1923. 